\title{
De forsvindende øers fremtidsfortællinger
}

Frits Andersen: Sydhavsøen - Nydelsens geografi. Aarhus: Aarhus Universitetsforlag 2018, 453 sider rigt ill., $399 \mathrm{kr}$.

Forestillinger om klodens fremtid er mere prægede af dystopier og dommedagsprofetier end af håb og positive visioner om en bedre verden. Og hvis man vender blikket mod de øer i det sydlige Stillehav, hvis eksistens er truet af vandstandsstigninger, kan enden synes særligt nær.

Men måske rummer de fortællinger, som opdagelsesrejsende, forfattere og kunstnere igennem de seneste århundreder har skrevet om netop øerne i det sydlige Stillehav et potentiale for mere håbefulde forestillinger om fremtiden. Det er et af afsættene for Frits Andersens imponerende og perspektivrige Sydhavsøen - Nydelsens geografi. Bogen er, hvad Frits Andersen kalder en "forsvindende øers litteraturhistorie", og denne litteraturhistorie er samtidig en undersøgelse af "idé- og litteraturhistoriske forudsætninger for påtrængende spørgsmål om globaliseringens konsekvenser for vores natursyn, økologi-, steds- og samfundsopfattelse" (s. 23).

Frits Andersen lægger ikke skjul på, at der er et opbyggeligt perspektiv i de forsvindende øers litteraturhistorie. Han skriver således, at det kun er "gennem en historisk forståelse, vi kan overskride den apokalyptiske tænkning, som præger økokritik og politik i dag. Fortællingerne om øen, øhavet og havet [...] er helt enkelt forbilledlige, når vi skal navigere i den antropocæne tidsalder" (s. 25-26). Sydhavsøernes litteraturhistorie skal altså bidrage til en ny form for øko- og geokritik, der er bedre i stand til at få greb om verdens aktuelle tilstand med klimaforandringer og globalisering.

Det er først og fremmest øer og øgrupper i Fransk Polynesien, der er i fokus i Sydhavsøen - især Tahiti, Marquesas-øerne og Tuamotu-atollerne. Ikke mindst Tahiti har i vestlige forestillinger fungeret som dén paradigmatiske $\varnothing$. Øer har historisk indtaget en særlig rolle som laboratorium for forestillinger om samfund, steder og verdener. Især fordi øer traditionelt opfattes som afgrænsede og overskuelige enklaver, har de dannet rammen for forskellige typer af utopiske forestillinger. Som Frits Andersen beskriver, er Tahiti f.eks. blevet set som et paradisisk sted, hvor livet primært handlede om nydelse: Naturens frugtbarhed betød, at beboerne ikke behøvede arbejde, men blot kunne tage for sig af retterne og nyde livet.

Det er ikke sydhavsøernes oprindelige kultur og fortællinger, der er bogens ærinde, men de vestlige forestillinger om og møder med øboerne og deres samfund: "Bogens inter-esse er netop, hvordan grundfæstede europæiske og amerikanske forestillinger om 
sted, natur og nation bliver afbøjet og kastet tilbage i mødet med Stillehavet og sydhavsøen" (s. 26). Således er f.eks. pastoralen som genre og teorier om det uopdagede kontinent Terra Australis Incognita nogle af de modeller, europæerne tager udgangspunkt i, i mødet med Stillehavets øer.

Frits Andersen er ikke tilbageholdende med, hvilke typer materiale der inddrages i bogen. Han begrænser ikke sin litteraturhistorie til fiktive, skønlitterære tekster, men inddrager også andre prosagenrer - bl.a. rejseberetninger, filosofiske og videnskabelige tekster - såvel som malerier, museer og andre "fænomener" som f.eks. Marlon Brandos $\varnothing$ kohotel på atollen Tetiora.

Det er altså et mangfoldigt materiale og et stort historisk spænd, Sydhavsøen gaber over, fra 1700-tallets opdagelser til i dag. Dette strukturerer Frits Andersen gennem tre overordnede stedskategorier, der også inddeler bogen i tre hovedafsnit: først 'Øen', dernæst ‘Øhavet' og til sidst 'Havet'. I første del er fokus på Tahiti, i anden på Marquesas- og Tuamotu-øerne og i tredje og sidste på Stillehavet. Forfattere og tekster placeres således alt efter, om deres formelle strategier og tematiske problematikker kredser om ‘øen', 'det arkipelagiske' eller 'det oceaniske'. I del 1 diskuteres - og problematiseres - bl.a. forestillingen om øen som en afgrænset, autonom enhed med udgangspunkt i George Robertson og Bourgainvilles rejseberetninger samt Gauguins Noa Noa og Pierre Lotis Le Mariage de Loti. I del 2 analyseres det arkipelagiske som et mere dynamisk princip baseret på vekslende og åbne relationer, og her er især Herman Melville, R.L. Stevenson og Jack London omdrejningspunkterne. Og i del 3 behandles havets "våde ontologi" som grundlag for "en postnational verdensorden med flydende og mobile grænser og identiteter" (s. 362), bl.a. ud fra analyser af Jules Vernes Lîle à hélice og Victor Segalens idé om "eksotismen".

Det bliver på den måde geografiens spatiale kategorier, der bliver styrende for bogens forløb og historieskrivning, frem for en kronologisk fremstilling. Denne "geokritiske" vinkel er velfungerende og relevant i forhold til stoffet, idet den stiller skarpt på centrale træk i forestillingerne om sydhavsøerne og tilbyder en prisme, hvorigennem forbindelserne mellem idéer om natur, sted og samfund kan analyseres.

Analyserne er generelt grundige, velskrevne og perspektivrige. Frits Andersen læser gennemgående teksterne både "kritisk" og "konstruktivt". På den ene side ved at afdække f.eks. de racistiske forestillinger, de kan rumme, eller de gennemgående illusioner om en oprindelig naturtilstands lyksaligheder. På den anden side ved at fremdrage de mere nuancerede og komplekse verdensbilleder, der også opstår i mødet med Sydhavsøerne; billeder, som hverken kan reduceres til naive idéer om den harmoniske natur eller til en kolonialistisk udnyttelse af natur og oprindelige folk. F.eks. skriver Diderot et "supplement" til Bourgainvilles rejseberetning, der af Frits Andersen læses som et markant eksempel på en sådan kompleks forståelse: "Hos Diderot [...] ses [...] omridset af en pragmatisk forståelse af samspillet mellem natur og samfund. Naturen er ikke udskilt som kulturens andet, men på hyperkompleks og dialektisk vis både det modsatte af og indeholdt i kulturen, og øens natur er ikke isoleret eller statisk utopisk, men beskrevet på baggrund af sin grundlæggende betingelse af udveksling med andre øer og kontinenter" (s. 106). Således har Sydhavsøen generelt et godt greb om de modsætninger, som utopiske forestillinger oftest rummer - f.eks. har utopier historisk været tæt forbundne med kolonialistiske projekter, samtidig med at de har fremstillet drømme om harmoniske og retfærdige samfund. 
Bogens analyser er gennemgående præget af et produktivt samspil mellem tekstnære læsninger og historisk kontekstualisering. De nævnte stedskategorier (øen, øhavet, havet) fungerer også som kontekstualiserende omdrejningspunkter, idet 'stedet' forstås "både som en specifik fysisk og geografisk lokalitet og som retorisk topos” (s. 24). På pragmatisk vis og med skiftende vægtninger inddrager Frits Andersen $\emptyset$ konomiske og politiske forhold, biografiske aspekter, klimatiske betingelser m.m. i sine analyser. Herigennem søger bogen at indfange de komplekse vekselvirkninger mellem disse mange forhold, samtidig med at stedskategorierne fungerer som strukturerende orienteringspunkter. Det er en af de væsentlige styrker ved bogens geokritiske koncept, at det langt hen ad vejen gør det muligt at holde sammen på de mange forskellige perspektiver og niveauer, der er på spil.

Der er dog enkelte afsnit, hvor det analytiske fokus alligevel kommer til at stå mindre skarpt. F.eks. i kapitel 2 i bogens tredje del, der bl.a. omhandler den forliste franskmand Jean Kabris, den europæiske kortlægning af Stillehavet og oversættelsen af den tahitianske præst Tupaias' kort - samt et moderne bud på et alternativt, 'kunstnerisk' atlas over Stillehavet. Her bliver de enkelte nedslag relativt kortfattede, og kapitlets fokus således lidt flakkende.

Mere kritisk kan man overordnet spørge, i hvor høj grad de utopiske fortællinger om sydhavsøer og -øgrupper reelt formår at bidrage til et fornyet håb om en fremtid. Frits Andersen foreslår hen mod bogens slutning, at "litteraturhistorien om forsvindende øer og nydelseskulturen [kan] være forbillede for en ny vending i økokritikken: I erkendelse af, at det netop er vores forskruede kontrol- og arbejdsetik, der ødelægger både livet og kloden, arbejdes der i stedet med planer for "hedonistisk bæredygtighed" indenfor arkitektur, ligesom filosoffer i dag taler for atter at give nydelsen forrang i både tænkning og livskunst" (s. 430). Men i hvor høj grad udgør "nydelsen" en alternativ model til den vestlige vækstkultur og -ideologi? Dyrkning af nydelsen fylder i forvejen meget i vestens kultur og indgår tilsyneladende uden problemer i en forbrugs- og vækstbaseret samfundsmodel.

Det positive forbillede må således forbindes med et kritisk perspektiv, hvis det skal kunne udgøre et alternativ til et bestående verdensbillede. Derfor er det også værd at betone, at utopier ikke kun handler om at beskrive positive, konstruktive modeller, men i mindst lige så høj grad om at stille skarpt på, hvad vi ikke kan forestille os, og på den måde undersøge grænserne for vores ideologiske forestillingsevne. Og her bidrager fortællingerne om sydhavsøerne især ved at udfordre idéerne om 'nationen' og 'arbejdsetikken’ som to af de måske mest rodfæstede ideologiske forestillinger i Vesten. Således er der et væsentligt og aktuelt utopisk potentiale i de forsvindende øers litteraturhistorie, og det kan bestemt anbefales at gå på opdagelse i Sydhavsøen.

Anmeldt af Mikkel Birk Jespersen 